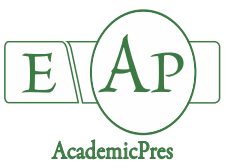

Akdağ Ş and Tuncer B (2020)
Notulae Botanicae Horti Agrobotanici Cluj-Napoca 48(2):1017-1026
DOI: $10.15835 /$ nbha48211935
Research Article

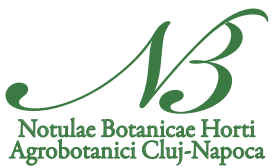

\title{
Effects of combined pretreatments on germination and emergence of wild Eremurus spectabilis M. Bieb. seeds
}

\author{
Şeref AKDAĞ${ }^{1}$, Burcu TUNCER ${ }^{2 *}$ \\ ${ }^{1}$ University of Van Yüzüncü Yul, Graduated School of Natural and Applied Sciences, Department of Horticulture, 65080, Van, \\ Turkey;seref_021@outlook.com \\ ${ }^{2}$ University of Van Yüzüncü Yll, Faculty of Agriculture, Department of Horticulture, 65080, Van, \\ Turkey;brctuncer@gmail.com (*corresponding author)
}

\begin{abstract}
Eremurus spectabilis is a perennial herbaceous species that grows in the wild. Commonly consumed as a vegetable, it is also classified among medicinal plants and popular ornamental geophytes. Germination is not achieved under normal conditions because of seed dormancy. In this study, various combined treatments were experimented with to improve the germination and emergence performance of E. spectabilis seeds. The seeds were immersed in solutions of potassium nitrate $\left(\mathrm{KNO}_{3}: 5 \mathrm{mM}\right.$ for 24 and 48 hours), calcium chloride $\left(\mathrm{CaCl}_{2}\right.$ : $5 \mathrm{mM}$ for 24 and 48 hours) and subjected to tip cutting. Pre-treated seeds were then subjected to moist-cold stratification periods treatments for different durations (30, 50, 80 and 100 days). In the $5 \mathrm{mM} \mathrm{KNO}_{3}$ treatments, 48-hour $\mathrm{KNO}_{3}$ and 100 days of stratification treatments had better germination (11.1\%) and emergence values (9.7\%). In the $5 \mathrm{mM} \mathrm{CaCl}_{2}$ treatments, 24-hour $\mathrm{CaCl}_{2}$ yielded better germination (10.2\%) and emergence $(8.4 \%)$ values. Seed tip-cutting treatments were the most successful among all the treatments for the germination and emergence parameters.
\end{abstract}

Keywords: $\mathrm{CaCl}_{2} ; \mathrm{KNO}_{3} ;$ Liliaceae; moist-cold stratification; seed dormancy

\section{Introduction}

E. spectabilis is a perennial herbaceous species growing in the wild and belonging to the Eremurus genus of the Liliaceae family (Tuzlac1, 1985). Plant shoots and leaves are cooked and consumed as a vegetable. Apart from nutritional values, the plants are also used for medicinal purposes. Different sections of the plant are used for treating fungal diseases, diabetes, jaundice and liver disorders (Tuzlacı and Doğan, 2010; Tosun et al., 2012; Pourfarzad et al., 2014). As with other Asia-originated Eremurus species, E. spectabilis has recently been categorized as a popular ornamental plant geophyte and used in cut-flower production practices, especially in mild climate zones (Schiappacasse et al., 2013).

Dormancy is also known as a seed-resting period, and it has been classified into five categories: physical, morphological, physiological, morphophysiological and combined (physical plus physiological) dormancy (Baskin and Baskin, 1998; Li et al., 1999; Baskin et al., 2000; Baskin and Baskin, 2004; Mamut et al., 2014). 
Physical dormancy results from unavailable water intake because of impervious seed testa or fruit skin. Some external treatments on seeds (high heat, varying temperature regimes, drying and abrasion of seed testa by mechanical means or acids) may make impervious layers permeable ( $\mathrm{Li}$ et al., 1999; Baskin et al., 2000). In morphological dormancy, the embryo is either not differentiated at all or differentiated but less-developed and small-sized. If a seed has an undifferentiated embryo during morphological dormancy, then there is no embryo and thus the radicle and cotyledon leaves are not formed. If a seed has a differentiated but less-developed embryo, as seen in species of the Apiaceae and Ranunculaceae families, then there are radicle and cotyledon leaves, but the embryo is smaller than $1 \mathrm{~mm}$. In species with less-developed embryos, there is no need for pretreatments to break the morphological dormancy of the seeds. It has been reported that when the seeds of these species were subjected to proper temperature and photoperiod regimes over moist papers based on species and embryo sizes, germination was observed in 4 weeks or under (Baskin and Baskin, 1998).

In physiological dormancy, the seeds are not able to germinate due to internal causes in the embryo, and the seeds should be subjected to moist-cold stratification treatments of varying durations to break the dormancy (Nikolaeva, 1969). Physiological dormancy could be severe, moderate or weak. To break the dormancy, the seeds generally need 10-16 weeks of moist-cold stratification for severe physiological dormancy, 8-14 weeks for moderate dormancy and 2-8 weeks for weak dormancy (Baskin and Baskin, 2004).

Morphophysiological dormancy occurs with the combined effect of morphological and physiological dormancy. In the seeds of species with morphophysiological dormancy, germination is not seen within 4 weeks, even when the seeds are subjected to proper temperature and photoperiod regimes. It is different from morphological dormancy in this sense (Baskin and Baskin, 2004). In several cold desert species of the Apiaceae, Araceae, Berberidaceae, Fumariaceae, Gentianaceae, Iridaceae, Liliaceae and Ranunculaceae families, the seeds have less-developed embryos (Baskin and Baskin, 1998).

Dormancy could occur due to either a single cause or the combined effects of different causes in some species. It is called a combined dormancy. In these cases, in addition to physical dormancy, physiological dormancy is observed (physical dormancy plus physiological dormancy). In some species, following the breaking of physical dormancy, moist-cold stratification treatments should be applied to break the physiological dormancy (Baskin and Baskin, 1998; Baskin et al., 2000). Dormancy-breaking treatments are applied to the seeds of several valuable plant species (Cho et al., 2018; Cho and Lee, 2018; Kırmızı et al., 2018). Such efficient dormancy-breaking practices should also be determined in E. spectabilis for seed propagation and further in vitro culture of the plants. A review of the literature reveals that the number of studies about the breaking of seed dormancy in E. spectabilis is very limited, and single dormancy-breaking treatments were applied in those studies rather than combined treatments (Güngör, 2002; Rahmanpour et al., 2005; Keskiner and Tuncer, 2019). In a previous study, conducted with E. spectabilis, $0.0 \%-73.3 \%$ of germination rate was achieved with moist-cold stratification treatments for different durations (Keskiner and Tuncer, 2019). In these studies, 100 days of cold stratification treatments were found to be the most promising treatment, and very low germination rates were reported for single potassium nitrate $\left(\mathrm{KNO}_{3}\right)$ and calcium chloride $\left(\mathrm{CaCl}_{2}\right)$ treatments without moist-cold stratification treatments (Keskiner and Tuncer, 2019). It was indicated that dormancy was persistent in E. spectabilis seeds, but positive outcomes were achieved with long-term ( 90 and 100 days) moist-cold stratification treatments.

It was thought that together with moist-cold stratification treatments, combined treatments could have positive impacts on the germination and the emergence of E. spectabilis seeds. With this study, the possible use of various combined treatments to shorten the germination duration of E. spectabilis seeds, which normally require 3-4 months for germination, was also investigated. In this study, combined with the moist-cold stratification treatments for different durations (at $4{ }^{\circ} \mathrm{C}$ for 30, 50, 80, and 100 days), $\mathrm{KNO}_{3}(5 \mathrm{mM}$ for 24 and 48 hours), $\mathrm{CaCl}_{2}$ ( $5 \mathrm{mM}$ for 24 and 48 hours) and seed tip-cutting treatments on the breaking of dormancy, germination and emergence performance of $E$. spectabilis seeds were investigated. 


\section{Materials and Methods}

\section{Plant materials and sterilization of seeds}

The E. spectabilis seeds used in the present experiments were supplied from the town of Gürpınar $\left(38^{\circ}\right.$ $8^{\prime} 20.75^{\prime \prime} \mathrm{N}, 43^{\circ} 30^{\prime} 55.15^{\prime \prime} \mathrm{E} ; 1,730 \mathrm{~m}$ ) in the province of Van, in Turkey. Seed sterilization was performed in two stages. In the first stage, to remove fungal disease agents, seeds were kept in a $0.3 \%$ Benomyl solution for an hour, washed with distilled water and kept in distilled water for 1 hour. In the second stage, the seeds were taken into a laminar flow cabinet, supplemented with 1-2 drops of Tween 20, kept in a $30 \%$ sodium hypochlorite solution $(\mathrm{NaOCl})$ for 10 minutes, rinsed three times with sterile distilled water for 5 minutes. Then, the seeds were placed on drying papers to remove any excess water. All the materials (glass petri dishes, drying papers, cotton, forceps, and distilled water) were sterilized in an autoclave (at $121^{\circ} \mathrm{C}, 1.2 \mathrm{~atm}$ pressure for 1.5 hours). Seed sowing and irrigation practices were performed in a laminar flow cabinet with sterile distilled water.

\section{Immersion in $\mathrm{KNO}_{3}$ or $\mathrm{CaCl}_{2}$ solution and moist-cold stratification treatments}

The sterilized seeds were immersed in $5 \mathrm{mM} \mathrm{KNO}_{3}$ or $\mathrm{CaCl}_{2}$ solutions for 24 and 48 hours then rinsed with sterile distilled water. Seeding was performed in petri dishes and they were subjected to moist-cold stratification treatments at $4^{\circ} \mathrm{C}$ for 30, 50, 80 and 100 days (Farzami Sepehr and Ghorbanli, 2011).

\section{Seed tip-cutting and moist-cold stratification treatments}

The sterilized seeds were taken into a sterile laminar flow cabinet and their tips were cut (Farzami Sepehr and Ghorbanli, 2011). Two layers of drying paper were placed base the petri dishes and tip-cut seeds were sown in petri dishes. Each treatment included three replications, each replicate (petri dish) containing 25 seeds. Then the petri dishes were placed in polyethylene bags and subjected to moist-cold stratification treatments at $4{ }^{\circ} \mathrm{C}$ for 30, 50, 80 and 100 days. Drying papers were moistened with $5 \mathrm{~mL}$ sterile distilled water when the moisture content decreased.

\section{Germination and emergence tests}

The seeds were germinated in an incubator at $12-13{ }^{\circ} \mathrm{C}$ under completely dark conditions until optimum germination was achieved (Güngör, 2002; Keskiner and Tuncer, 2019). In all treatments, a 2 mm elongation of radicle from the seed testa was considered as the germination criterion, and the period in which the cotyledon leaf extended parallel to the ground was considered as the emergence criterion. For every treatment, germination and emergence were counted final count until no further germination and emergence occurred. The counts started at the end of the moist-cold stratification treatments and were done with an interval of 3 days. At the end of the tests, the germination ratio (GR), emergence ratio (ER), germination speed (GS), emergence speed (ES), mean germination time (MGT), mean emergence time (MET), vigour index (VI), radicle length (RL), plumule length (PL) and seedling length $(\mathrm{SL})(\mathrm{cm})$ were calculated. The following equations were used in the calculations (Abdul-baki and Anderson, 1973; Murillo-Amador et al., 2002):

$$
\begin{aligned}
& (\mathrm{GR})(\mathrm{ER})(\%)=\frac{G}{T} \times 100 \\
& (\mathrm{MGT})(\mathrm{MET})(\text { day })=\frac{[(1 . \text { day } G \times 1 . \text { day })+(2 . \text { day } G \times 2 . \text { day })+\cdots+(\text { n.day } G \times n . \text { day })}{\text { Total } G}
\end{aligned}
$$

Germination or emergence speed $=\frac{n 1}{t 1}+\frac{n 2}{t 2}+\cdots+\frac{n n}{t n}$

Vigor index $=L s \times \frac{G R}{100}$

In the equations: $\mathrm{n} 1, \mathrm{n} 2$ : number of germinated or emerged seeds; $\mathrm{t} 1, \mathrm{t} 2$ : number of days for germination or emergence; Ls: Mean radicle + plumule length; $G=$ germinated or emerged seeds; $T=$ total number of seeds. 


\section{Statistical analysis}

The germination and emergence experiments were conducted in a completely randomized block design with three replications ( 25 seeds per replicate). Data for germination and emergence parameters were subjected to arcsine transformation before statistical analysis. The data were statistically analysed using analysis of variance (ANOVA) with Statgraphics statistical software, followed by Duncan's multiple range test comparisons for significant differences.

\section{Results}

In all applications, the control group (seeds without any treatment) was excluded from the experiment since there was no germination in the control group.

\section{Combined effects of immersion in a $\mathrm{KNO}_{3}$ solution and moist-cold stratification treatments}

The combined effects of $\mathrm{KNO}_{3}$ and moist-cold stratification treatments on the germination parameters are presented in Table 1.

Table 1. Effect of immersion in $\mathrm{KNO}_{3}$ solution $(5 \mathrm{mM})$ and stratification period (MCST) for germination rate (GR), germination speed (GS) and mean germination time (MGT)

\begin{tabular}{|c|c|c|c|c|}
\hline $\mathrm{KNO}_{3}$ & $\begin{array}{c}\text { Stratification period } \\
\text { (day) }\end{array}$ & GR $(\%) \pm$ S.E. & GS (day) \pm S.E. & MGT (day) \pm S.E. \\
\hline \multirow{4}{*}{$24 \mathrm{~h}$} & 30 & $0.0 \pm 0.0 \mathrm{c}$ & $0.0 \pm 0.0 \mathrm{~b}$ & $0.0 \pm 0.0 \mathrm{~d}$ \\
\hline & 50 & $0.0 \pm 0.0 \mathrm{c}$ & $0.0 \pm 0.0 \mathrm{~b}$ & $0.0 \pm 0.0 \mathrm{~d}$ \\
\hline & 80 & $0.0 \pm 0.0 \mathrm{c}$ & $0.0 \pm 0.0 \mathrm{~b}$ & $0.0 \pm 0.0 \mathrm{~d}$ \\
\hline & 100 & $29.2 \pm 2.1 \mathrm{a}$ & $0.5 \pm 0.3 \mathrm{a}$ & $41.1 \pm 1.2 \mathrm{~b}$ \\
\hline \multicolumn{2}{|r|}{ Average } & $7.3 \pm 3.8^{2}$ & $0.1 \pm 0.1$ & $10.3 \pm 5.4^{2}$ \\
\hline \multirow{4}{*}{$48 \mathrm{~h}$} & 30 & $1.9 \pm 0.4 \mathrm{c}$ & $0.1 \pm 0.1 \mathrm{ab}$ & $2.3 \pm 0.3 \mathrm{~d}$ \\
\hline & 50 & $1.9 \pm 0.4 \mathrm{c}$ & $0.02 \pm 0.1 \mathrm{~b}$ & $4.6 \pm 1.4 \mathrm{~d}$ \\
\hline & 80 & $13.0 \pm 1.9 \mathrm{~b}$ & $0.4 \pm 0.2 \mathrm{ab}$ & $30.0 \pm 2.8 \mathrm{c}$ \\
\hline & 100 & $27.8 \pm 0.1 \mathrm{a}$ & $0.1 \pm 0.1 \mathrm{ab}$ & $50.2 \pm 3.6 \mathrm{a}$ \\
\hline \multicolumn{2}{|r|}{ Average } & $11.1 \pm 3.2^{1}$ & $0.2 \pm 0.1$ & $21.8 \pm 6.0^{1}$ \\
\hline \multirow{4}{*}{$\begin{array}{l}\text { Average of } \\
\text { MCST }\end{array}$} & 30 & $0.9 \pm 0.4 \mathrm{C}$ & $0.05 \pm 0.02$ & $1.2 \pm 0.5 \mathrm{C}$ \\
\hline & 50 & $0.9 \pm 0.4 \mathrm{C}$ & $0.01 \pm 0.01$ & $2.3 \pm 1.2 \mathrm{C}$ \\
\hline & 80 & $6.5 \pm 2.0 \mathrm{~B}$ & $0.2 \pm 0.1$ & $15.0 \pm 6.8 \mathrm{~B}$ \\
\hline & 100 & $28.4 \pm 0.9 \mathrm{~A}$ & $0.3 \pm 0.2$ & $45.6 \pm 2.6 \mathrm{~A}$ \\
\hline \multicolumn{5}{|c|}{ P Value } \\
\hline \multicolumn{2}{|r|}{$\mathrm{KNO}_{3}$} & $0.000^{* *}$ & $\mathrm{~ns}$ & $0.000^{* *}$ \\
\hline \multicolumn{2}{|r|}{ MCST } & $0.000^{* *}$ & $\mathrm{~ns}$ & $0.000^{* *}$ \\
\hline \multicolumn{2}{|c|}{$\mathrm{KNO}_{3} \times \mathrm{MCST}$} & $0.000^{* *}$ & $\mathrm{~ns}$ & $0.000^{* *}$ \\
\hline
\end{tabular}

Different capital letters in the same column indicate the differences among the moist-cold stratification period, different numbers indicate the differences among $\mathrm{KNO}_{3}$ duration and different small letters indicate significant the differences between interactions (Duncan test, ${ }^{* *}: \mathrm{p}<0.01$ ), ns: no significant difference

With regard to GR and MGT, differences between the treatments and interactions were found to be significant $(\mathrm{p}<0.01)$. For the $\mathrm{GR}$, a 48-hour $\mathrm{KNO}_{3}$ treatment $(11.1 \%)$ was more successful than a 24-hour treatment $(7.3 \%)$. While germination was achieved in only 100 days of stratification treatments $(29.2 \%)$ in the 24-hour $\mathrm{KNO}_{3}$ treatment, germination was achieved in both the 100 days (27.8\%) and 80 days (13.0\%) of moist-cold stratification treatments in the 48 -hour $\mathrm{KNO}_{3}$ treatments (Table 1). The emergence parameters are summarized in Table 2. The greatest ER in both $\mathrm{KNO}_{3}$ immersion durations ( 24 and 48 hours) was obtained from 100 days of stratification treatments. For the ER (9.7), RL $(0.3 \mathrm{~cm})$, PL $(3.0 \mathrm{~cm}), \mathrm{SL}(3.3 \mathrm{~cm})$ 
and VI, $5 \mathrm{mM} \mathrm{KNO}_{3}$ (48 hours) and 100 days of stratification treatments was more successful (Table 2). In the 48-hour $\mathrm{KNO}_{3}$ treatments, the best GR (27.8\%) and ER (25.9\%) were again obtained from 100 days of stratification treatments. With regard to the effects of different immersion durations in a $5 \mathrm{mM} \mathrm{KNO}_{3}$ solution, it was observed that 48 hours yielded better outcomes for all the germination and emergence parameters than did 24 hours. On average in the 48 -hour $\mathrm{KNO}_{3}$ treatments, the GR, ER, MGT and MET were measured $11.1 \%, 9.7 \%, 21.8$ days and 21.7 days, respectively (Table 1 and Table 2).

\section{Combined effects of immersion in a $\mathrm{CaCl}_{2}$ solution and moist-cold stratification treatments}

Contrary to the $\mathrm{KNO}_{3}$ treatments, better $\mathrm{GR}$ were achieved with 24-hour $\mathrm{CaCl}_{2}$ immersion durations than with 48-hour immersion. The greatest GR (33.3\%) was obtained from 24-hour $\mathrm{CaCl}_{2}$ and 100 days of moist-cold stratification treatments. MGT varied between 0.0 and 43.0 days (Table 3 ).

The effects of immersion in $\mathrm{CaCl}_{2}$ solution $(5 \mathrm{mM})$ and stratification period on the emergence parameters are presented in Table 4. Considering the effects of different immersion periods in $5 \mathrm{mM} \mathrm{CaCl}$ solution, it was observed that 24-hour treatments yielded a better ER (8.4\%) and 48-hour treatments yielded better PL $(2.8 \mathrm{~cm})$ and SL $(3.1 \mathrm{~cm})$. The greatest ER $(26.1 \%)$ was obtained from 24 hours $\mathrm{CaCl}_{2}$ and 100 days of stratification treatments (Table 4).

Table 2. Effect of immersion in $\mathrm{KNO}_{3}$ solution $(5 \mathrm{mM})$ and stratification period (MCST) for emergence rate (ER), emergence speed (ES), mean emergence time (MET), radicle length (RL), plumule length (PL), seedling length (SL) and vigour index (VI)

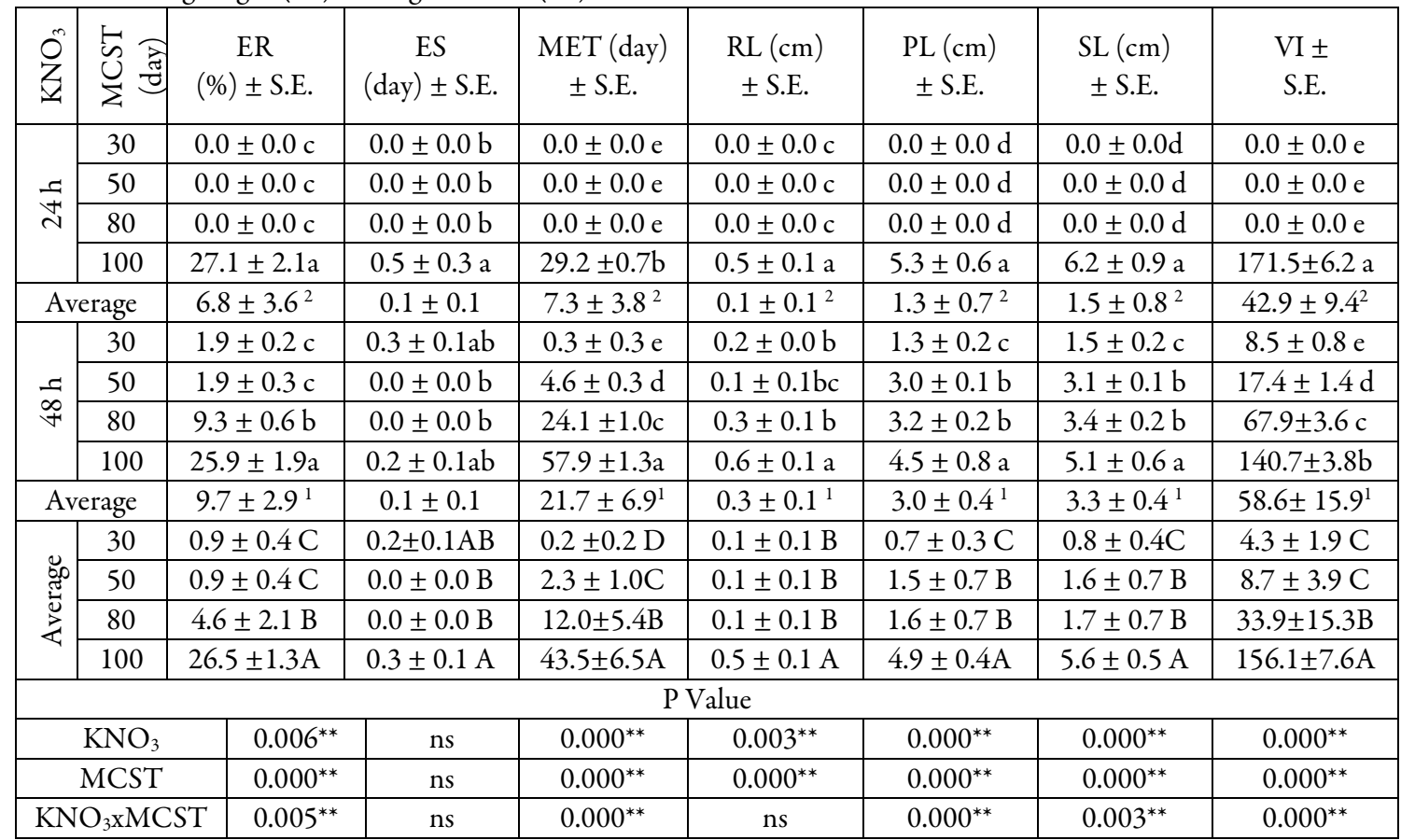

Different capital letters in the same column indicate the differences among the moist-cold stratification period, different numbers indicate the differences among $\mathrm{KNO}_{3}$ duration and different small letters indicate significant the differences between interactions, Duncan test, ${ }^{* *}: \mathrm{p}<0.01$, ns: no significant difference 
Table 3. Effect of immersion in $\mathrm{CaCl}_{2}$ solution $(5 \mathrm{mM})$ and stratification period (MCST) for germination rate (GR), germination speed (GS) and mean germination time (MGT)

\begin{tabular}{|c|c|c|c|c|}
\hline $\mathrm{CaCl}_{2}$ & $\begin{array}{c}\text { Stratification period } \\
\text { (day) }\end{array}$ & GR $(\%) \pm$ S.E. & GS (day) \pm S.E. & MGT (day) \pm S.E. \\
\hline \multirow{4}{*}{$24 \mathrm{~h}$} & 30 & $1.8 \pm 0.2 \mathrm{~d}$ & $0.03 \pm 0.0$ & $0.3 \pm 0.1 \mathrm{e}$ \\
\hline & 50 & $0.0 \pm 0.0 \mathrm{~d}$ & $0.0 \pm 0.0$ & $0.0 \pm 0.0 \mathrm{e}$ \\
\hline & 80 & $5.5 \pm 0.3 b-d$ & $0.4 \pm 0.2$ & $7.9 \pm 0.4 \mathrm{~d}$ \\
\hline & 100 & $33.3 \pm 6.6 \mathrm{a}$ & $0.7 \pm 0.2$ & $43.0 \pm 2.8 \mathrm{a}$ \\
\hline \multicolumn{2}{|r|}{ Average } & $10.2 \pm 4.3^{1}$ & $0.3 \pm 0.1$ & $12.8 \pm 5.4$ \\
\hline \multirow{4}{*}{$48 \mathrm{~h}$} & 30 & $0.0 \pm 0.0 \mathrm{~d}$ & $0.0 \pm 0.0$ & $0.0 \pm 0.0 \mathrm{e}$ \\
\hline & 50 & $3.7 \pm 0.4 \mathrm{~cd}$ & $0.4 \pm 0.2$ & $0.3 \pm 0.1 \mathrm{e}$ \\
\hline & 80 & $11.1 \pm 0.3 \mathrm{~b}$ & $0.06 \pm 0.0$ & $28.0 \pm 0.1 \mathrm{~b}$ \\
\hline & 100 & $9.3 \pm 0.7 b c$ & $0.7 \pm 0.2$ & $22.1 \pm 2.5 \mathrm{c}$ \\
\hline \multicolumn{2}{|r|}{ Average } & $6.0 \pm 1.3^{2}$ & $0.3 \pm 0.1$ & $12.6 \pm 3.8$ \\
\hline \multirow{4}{*}{$\begin{array}{l}\text { Average of } \\
\text { MCST }\end{array}$} & 30 & $0.9 \pm 0.4 \mathrm{C}$ & $0.01 \pm 0.01 \mathrm{~B}$ & $0.2 \pm 0.1 \mathrm{C}$ \\
\hline & 50 & $1.9 \pm 0.8 \mathrm{C}$ & $0.2 \pm 0.01 \mathrm{~B}$ & $0.2 \pm 0.1 \mathrm{C}$ \\
\hline & 80 & $8.3 \pm 1.3 \mathrm{~B}$ & $0.2 \pm 0.1 \mathrm{~B}$ & $17.9 \pm 4.5 \mathrm{~B}$ \\
\hline & 100 & $21.3 \pm 6.2 \mathrm{~A}$ & $0.7 \pm 0.2 \mathrm{~A}$ & $32.6 \pm 5.0 \mathrm{~A}$ \\
\hline \multicolumn{5}{|c|}{ P Value } \\
\hline \multicolumn{2}{|r|}{$\mathrm{CaCl}_{2}$} & $0.027^{*}$ & $\mathrm{~ns}$ & $\mathrm{~ns}$ \\
\hline \multicolumn{2}{|r|}{ MCST } & $0.000^{* *}$ & $0.020^{*}$ & $0.000^{* *}$ \\
\hline \multicolumn{2}{|c|}{$\mathrm{CaCl}_{2} \times \mathrm{MCST}$} & $0.001^{* *}$ & $0.477^{*}$ & $0.000^{* *}$ \\
\hline
\end{tabular}

Different capital letters in the same column indicate the differences among the moist-cold stratification period, different numbers indicate the differences among $\mathrm{CaCl}_{2}$ duration and different small letters indicate significant the differences between interactions, Duncan test, ${ }^{*}: \mathrm{p}<0.05,{ }^{* *}$ : $\mathrm{p}<0.01$, ns: no significant difference

Table 4. Effect of immersion in $\mathrm{CaCl}_{2}$ solution $(5 \mathrm{mM})$ and stratification period (MCST) for emergence rate (ER), emergence speed (ES), mean emergence time (MET), radicle length (RL), plumule length (PL), seedling length (SL) and vigour index $(\mathrm{VI})$

\begin{tabular}{|c|c|c|c|c|c|c|c|c|}
\hline Ũ & 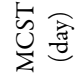 & $\begin{array}{c}\text { ER (\%) } \\
\pm \text { S.E. }\end{array}$ & $\begin{array}{c}\text { ES (day) } \\
\pm \text { S.E. }\end{array}$ & $\begin{array}{c}\text { MET (day) } \\
\pm \text { S.E. }\end{array}$ & $\begin{array}{l}\mathrm{RL}(\mathrm{cm}) \\
\pm \mathrm{S} . \mathrm{E} .\end{array}$ & $\mathrm{PL}(\mathrm{cm}) \pm$ S.E. & $\mathrm{SL}(\mathrm{cm}) \pm \mathrm{S} . \mathrm{E}$. & $\mathrm{VI} \pm \mathrm{S} . \mathrm{E}$ \\
\hline \multirow{4}{*}{$\stackrel{\mathbb{d}}{d}$} & 30 & $1.9 \pm 0.2 \mathrm{de}$ & $\begin{array}{c}0.01 \pm 0.0 \\
\mathrm{~b}\end{array}$ & $\begin{array}{c}16.3 \pm 2.4 \\
c\end{array}$ & $\begin{array}{c}0.1 \pm 0.0 \\
\mathrm{de}\end{array}$ & $\begin{array}{c}1.0 \pm 0.1 \\
\mathrm{~cd}\end{array}$ & $\begin{array}{c}1.1 \pm 0.1 \\
\mathrm{~cd}\end{array}$ & $\begin{array}{c}6.3 \pm 0.4 \\
\mathrm{e}\end{array}$ \\
\hline & 50 & $0.0 \pm 0.0 \mathrm{e}$ & $0.0 \pm 0.0 \mathrm{~b}$ & $0.0 \pm 0.0 \mathrm{e}$ & $0.0 \pm 0.0 \mathrm{e}$ & $0.0 \pm 0.0 \mathrm{~d}$ & $0.0 \pm 0.0 \mathrm{~d}$ & $0.0 \pm 0.0 \mathrm{e}$ \\
\hline & 80 & $5.6 \pm 0.3 c$ & $0.7 \pm 0.3 \mathrm{a}$ & $3.3 \pm 0.9 \mathrm{~d}$ & $0.2 \pm 0.1 \mathrm{~cd}$ & $1.3 \pm 0.3 \mathrm{~cd}$ & $1.6 \pm 0.3 \mathrm{~cd}$ & $20.5 \pm 2.5 \mathrm{~d}$ \\
\hline & 100 & $26.1 \pm 1.2 \mathrm{a}$ & $0.2 \pm 0.1 \mathrm{ab}$ & $32.1 \pm 0.3 \mathrm{a}$ & $0.5 \pm 0.1 \mathrm{a}$ & $4.3 \pm 1.2 \mathrm{ab}$ & $4.8 \pm 1.2 \mathrm{ab}$ & $119.9 \pm 5.7 \mathrm{a}$ \\
\hline \multicolumn{2}{|c|}{ Average } & $8.4 \pm 3.2^{1}$ & $0.2 \pm 0.1$ & $12.9 \pm 3.8$ & $0.2 \pm 0.1$ & $1.7 \pm 0.5^{2}$ & $1.9 \pm 0.6^{2}$ & $36.7 \pm 10.2$ \\
\hline \multirow{4}{*}{ 秀 } & 30 & $0.0 \pm 0.0 \mathrm{e}$ & $0.0 \pm 0.0$ & $0.0 \pm 0.0 \mathrm{e}$ & $0.0 \pm 0.0 \mathrm{e}$ & $0.0 \pm 0.0 \mathrm{~d}$ & $0.0 \pm 0.0 \mathrm{~d}$ & $0.0 \pm 0.0 \mathrm{e}$ \\
\hline & 50 & $3.7 \pm 0.3 \mathrm{~cd}$ & $0.4 \pm 0.2 \mathrm{ab}$ & $0.3 \pm 0.2 \mathrm{de}$ & $0.2 \pm 0.1 \mathrm{~cd}$ & $2.3 \pm 0.3 b c$ & $2.5 \pm 0.3 b c$ & $27.8 \pm 3.0 \mathrm{~d}$ \\
\hline & 80 & $11.1 \pm 0.9 b$ & $0.05 \pm 0.01$ & $25.8 \pm 1.1 \mathrm{~b}$ & $0.4 \pm 0.1 \mathrm{ab}$ & $6.0 \pm 1.0 \mathrm{a}$ & $6.4 \pm 1.1 \mathrm{a}$ & $77.1 \pm 1.7 \mathrm{~b}$ \\
\hline & 100 & $9.3 \pm 1.1 \mathrm{~b}$ & $0.2 \pm 0.1 \mathrm{ab}$ & $23.9 \pm 0.6 b$ & $0.3 \pm 0.1 b c$ & $3.0 \pm 1.2 b c$ & $3.3 \pm 1.2 \mathrm{bc}$ & $43.3 \pm 1.6 c$ \\
\hline \multicolumn{2}{|c|}{ Average } & $6.0 \pm 1.3^{2}$ & $0.2 \pm 0.1$ & $12.5 \pm 3.7$ & $0.2 \pm 0.1$ & $2.8 \pm 0.7^{1}$ & $3.1 \pm 0.7^{1}$ & $37.1 \pm 8.4$ \\
\hline \multirow{4}{*}{ 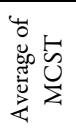 } & 30 & $0.9 \pm 04 \mathrm{C}$ & $0.05 \pm 0.0$ & $8.2 \pm 3.8 \mathrm{C}$ & $0.06 \pm 0.0 \mathrm{~B}$ & $0.5 \pm 0.2 \mathrm{~B}$ & $0.6 \pm 0.2 \mathrm{~B}$ & $3.1 \pm 1.4 \mathrm{D}$ \\
\hline & 50 & $1.9 \pm 0.8 \mathrm{C}$ & $0.2 \pm 0.1$ & $0.2 \pm 0.2 \mathrm{D}$ & $0.08 \pm 0.0 \mathrm{~B}$ & $1.2 \pm 0.5 \mathrm{~B}$ & $1.3 \pm 0.6 \mathrm{~B}$ & $13.9 \pm 6.4 \mathrm{C}$ \\
\hline & 80 & $8.3 \pm 1.3 \mathrm{~B}$ & $0.4 \pm 0.2$ & $14.6 \pm 5.0 \mathrm{~B}$ & $0.3 \pm 0.1 \mathrm{~A}$ & $3.7 \pm 1.2 \mathrm{~A}$ & $3.9 \pm 1.2 \mathrm{~A}$ & $48.8 \pm 12.7 \mathrm{~B}$ \\
\hline & 100 & $17.7 \pm 3.8 \mathrm{~A}$ & $0.2 \pm 0.1$ & $27.9 \pm 1.8 \mathrm{~A}$ & $0.4 \pm 0.1 \mathrm{~A}$ & $3.7 \pm 0.8 \mathrm{~A}$ & $4.0 \pm 0.8 \mathrm{~A}$ & $81.6 \pm 17.3 \mathrm{~A}$ \\
\hline \multicolumn{9}{|c|}{ P Value } \\
\hline \multicolumn{2}{|c|}{$\mathrm{CaCl}_{2}$} & $0.004^{* *}$ & $\mathrm{~ns}$ & $\mathrm{~ns}$ & ns & $0.043^{*}$ & $0.009^{* *}$ & ns \\
\hline \multicolumn{2}{|c|}{ MCST } & $0.000^{* *}$ & $\mathrm{~ns}$ & $0.000^{* *}$ & $0.000^{* *}$ & $0.009^{* *}$ & $0.007^{* *}$ & $0.000^{* *}$ \\
\hline \multicolumn{2}{|c|}{$\mathrm{CaCl}_{2} \times \mathrm{MCST}$} & $0.000^{* *}$ & $\mathrm{~ns}$ & $0.000^{* *}$ & $0.007^{* *}$ & $0.003^{* *}$ & $0.003^{* *}$ & $0.000^{* *}$ \\
\hline
\end{tabular}

Different capital letters in the same column indicate the differences among the moist-cold stratification period, different numbers indicate the differences among $\mathrm{CaCl}_{2}$ time and different small letters indicate significant the differences between interactions, Duncan test, ${ }^{*}: \mathrm{p}<0.05,{ }^{* *}: \mathrm{p}<0.01$, ns: no significant difference 


\section{Combined effects of seed tip-cutting and moist-cold stratification treatments}

Moist-cold stratification of tip-cut seeds for different periods was the most successful among all the treatments. Differences in GR and MGT were not found to be significant (Table 5). The greatest GR were obtained from 100 days $(60.6 \%)$ and 80 days $(51.5 \%)$ of stratification treatments. The GR of $45.5 \%$ was achieved, even with 30 days of stratification treatments. It is quite remarkable in the present study that high germination and emergence values were achieved in tip-cut seeds, even with short stratification durations. Based on stratification durations, GR varied between $45.5 \%$ and $60.6 \%$ and ER varied between $21.4 \%$ and 29.3\%. Tip-cutting treatments also shortened MGT (9.5-15.0 days) and MET (8.4-11.3 days) of E. spectabilis seeds when compared with the other treatments (Table 5 and Table 6).

Table 5. Effects of moist-cold stratification periods on germination parameters of tip-cut seeds (GR: germination rate, GS: germination speed, MGT: mean germination time)

\begin{tabular}{|c|c|c|c|}
\hline Stratification period (day) & GR $(\%) \pm$ S.E. & GS (day) \pm S.E. & MGT (day) \pm S.E. \\
\hline 30 & $45.5 \pm 10.1$ & $3.0 \pm 1.0 \mathrm{~b}$ & $13.3 \pm 2.1$ \\
\hline 50 & $45.5 \pm 2.6$ & $2.3 \pm 0.4 \mathrm{~b}$ & $12.1 \pm 1.8$ \\
\hline 80 & $51.5 \pm 4.0$ & $3.4 \pm 0.3 \mathrm{~b}$ & $15.0 \pm 2.4$ \\
\hline 100 & $60.6 \pm 3.0$ & $5.4 \pm 0.3 \mathrm{a}$ & $9.5 \pm 2.6$ \\
\hline P Value & $\mathrm{ns}$ & $0.034^{*}$ & $\mathrm{~ns}$ \\
\hline
\end{tabular}

Different small letters in the same column indicate the differences among the moist-cold stratification period, Duncan test, ${ }^{*}: \mathrm{p}<0.05$, ns: no significant difference

Table 6. Effects of moist-cold stratification periods on emergence parameters of tip-cut seeds (ER: emergence rate, ES: emergence speed, MET: mean emergence time, RL: radicle length, PL: plumule length, SL: seedling length and VI: vigour index)

\begin{tabular}{|c|c|c|c|c|c|c|c|}
\hline $\begin{array}{c}\text { Stratification } \\
\text { period (day) }\end{array}$ & $\begin{array}{c}\text { ER }(\%) \\
\pm \text { S.E. }\end{array}$ & $\begin{array}{c}\text { ES (day) } \\
\pm \text { S.E. }\end{array}$ & $\begin{array}{c}\text { MET (day) } \\
\pm \text { S.E. }\end{array}$ & $\begin{array}{c}\text { RL }(\mathrm{cm}) \\
\pm \text { S.E. }\end{array}$ & $\begin{array}{c}\text { PL }(\mathrm{cm}) \\
\pm \text { S.E. }\end{array}$ & $\begin{array}{c}\text { SL }(\mathrm{cm}) \\
\pm \text { S.E. }\end{array}$ & $\begin{array}{c}\text { VI } \\
\pm \text { S.E }\end{array}$ \\
\hline 30 & $21.4 \pm 1.5 \mathrm{~b}$ & $1.4 \pm 0.1$ & $8.4 \pm 0.4 \mathrm{~b}$ & $0.5 \pm 0.1$ & $5.8 \pm 0.7$ & $6.3 \pm 0.7$ & $366.9 \pm 42.1$ \\
\hline 50 & $23.0 \pm 1.2 \mathrm{~b}$ & $1.1 \pm 0.3$ & $11.3 \pm 0.7 \mathrm{a}$ & $0.5 \pm 0.1$ & $6.5 \pm 1.5$ & $7.0 \pm 1.5$ & $348.8 \pm 3.5$ \\
\hline 80 & $24.9 \pm 1.7 \mathrm{ab}$ & $1.1 \pm 0.2$ & $10.3 \pm 0.7 \mathrm{ab}$ & $0.9 \pm 0.4$ & $6.3 \pm 0.2$ & $7.3 \pm 0.6$ & $353.6 \pm 26.2$ \\
\hline 100 & $29.3 \pm 1.1 \mathrm{a}$ & $1.5 \pm 0.3$ & $8.9 \pm 0.6 \mathrm{~b}$ & $1.1 \pm 0.4$ & $5.8 \pm 1.2$ & $6.9 \pm 1.6$ & $354.2 \pm 38.5$ \\
\hline P Value & $0.022^{*}$ & $\mathrm{~ns}$ & $0.033^{*}$ & $\mathrm{~ns}$ & $\mathrm{~ns}$ & $\mathrm{~ns}$ & $\mathrm{~ns}$ \\
\hline
\end{tabular}

Different small letters in the same column indicate the differences among the moist-cold stratification period, Duncan test, ${ }^{*}: \mathrm{p}<0.05$, ns: no significant difference

\section{Discussion}

Keskiner (2017) and Keskiner and Tuncer (2019) applied different doses of $\mathrm{KNO}_{3}(0,5 \mathrm{mM}, 10 \mathrm{mM}$, and $15 \mathrm{mM}$ ) to break the dormancy in E. spectabilis seeds and reported that a $5 \mathrm{mM} \mathrm{KNO}_{3}$ yielded better germination rate and emergence rate than the other doses and indicated drastically decrease in germination and emergence values with increasing doses. In the present study, in the 24-hour $\mathrm{KNO}_{3}$ treatments, the greatest germination rate $(29.2 \%)$ and emergence rate $(27.1 \%)$ were obtained from 100 days of stratification treatments, but germination and emergence were not achieved in other stratification durations of the 24-hour $\mathrm{KNO}_{3}$ treatments (Table 1 and Table 2).

Keskiner (2017) reported the mean germination rate and mean germination time for a $5 \mathrm{mM} \mathrm{KNO}_{3}$ dose as $10 \%$ and 43.68 days, respectively, and reported the mean emergence rate and mean emergence time as $3.33 \%$ and 31.16 days, respectively. Present germination rate and especially emergence rate were greater than the values Keskiner (2017) reported. Such increases primarily resulted from the combined effects of immersion durations in a $\mathrm{KNO}_{3}$ solution and stratification treatments. Güngör (2002) reported no positive outcomes for germination of E. spectabilis seeds subjected to $\mathrm{KNO}_{3}$ treatments (0.2\%). In another study, Tulipa 
kaufmanniana Regel (Liliaceae) seeds were subjected to cold stratification and $\mathrm{KNO}_{3}$ treatments together, and the greatest germination ratio was reported for $\mathrm{KNO}_{3}(0.1 \%)$ and 7 weeks of cold stratification treatments (Rouhi et al., 2010).

Keskiner (2017) and Keskiner and Tuncer (2019) applied different doses of $\mathrm{CaCl}_{2}(0,5 \mathrm{mM}, 10 \mathrm{mM}$, and $15 \mathrm{mM}$ ) to E. spectabilis seeds and reported that the $5 \mathrm{mM}$ dose yielded a better GR (3.33\%) and ER (2.66\%) than the other doses. Present findings were much greater than the values Keskiner (2017) reported. Such increases mainly resulted from the combined effects of $\mathrm{CaCl}_{2}$ and stratification treatments.

Rahmanpour et al. (2005), for E. spectabilis, and Rahmanpour et al. (2007), for E. olgae, reported that the mechanical abrasion of seeds with some chemicals and tip-cutting treatments had positive impacts on germination and emergence parameters. At the end of 3 weeks, Rahmanpour et al. (2005) reported the greatest germination rate $(53.3 \%)$ and germination speed (0.88 days) for tip-cut seeds of E. spectabilis subjected to a pretreatment of immersion in a 35\% sodium hypochlorite solution for 24 and 48 hours and $0.01 \mathrm{M} \mathrm{GA}_{3}$ and citric acid ( $\left.50 \mathrm{mg} \mathrm{L}^{-1}\right)$ solutions for 45 minutes. In the present study, a greater GR (60.6\%) was achieved. In another study, Rahmanpour et al. (2007) reported a 70\% germination rate for citric acid-treated tip-cut seeds of $E$. olgae and $80 \%$ germination ratio for different combined treatments (immersion in water for $24-48$ hours plus tip-cutting plus immersion in a $0.08 \mathrm{M} \mathrm{GA}_{3}$ solution for 45 minutes). Such findings do not comply with the present ones because of the different species used. It was reported in a previous study by the present researchers (Keskiner and Tuncer, 2019) and in Güngör (2002) that without any pre-treatments, dormancy in E. spectabilis seeds was able to be broken only with moist-cold stratification treatments for a 2-3 month-long duration. According to Baskin and Baskin (2004), if a species requires 8-14 weeks of moist-cold stratification, this species has a moderate physiological dormancy. Such findings indicate that E. spectabilis exhibits moderate physiological dormancy.

With regard to the morphophysiological dormancy of E. spectabilis seeds, again, according to Baskin and Baskin (2004), if there is no germination in seeds taken under appropriate conditions within 4 weeks, these seeds may have a morphophysiological dormancy. Both in the present study and in a previous study by the same researchers (Keskiner and Tuncer, 2019), germination was not observed in Espectabilis seeds without any pretreatments (control group) within 4 weeks, even when the seeds were manipulated under appropriate conditions. A combined dormancy (physical dormancy plus physiological dormancy) may be seen in some species (Baskin and Baskin, 1998; Baskin et al., 2000). Following the breaking of physical dormancy, there is a need for moist-cold stratification treatments to break the physiological dormancy. In the present study, germination was achieved in tip-cut seeds in less than 30 days when the seeds were subjected to moist-cold stratification treatments. Such findings indicate that E. spectabilis has a combined dormancy.

\section{Conclusions}

Based on the present findings, it can be concluded that in both in vitro and field germination studies of E. spectabilis, moist-cold stratification treatments for short periods ( $<30$ days) to tip-cut seeds could improve germination rate and emergence rate and dramatically shorten mean germination time and mean emergence time. The present findings may guide future researchers in solving dormancy problems in E. spectabilis and in further culture practices with E. spectabilis.

\section{Acknowledgements}

Authors would like to thank Van Yüzüncü Yıl University, Scientific Research Projects Department for the financial support (Project No: FYL-2017-6581). This study was a part of the MSc thesis of the first author. 
Akdağ Ş and Tuncer B (2020). Not Bot Horti Agrobo 48(2):1017-1026

\section{Conflict of Interests}

The authors declare that there are no conflicts of interest related to this article.

\section{References}

Abdul Baki AA, Anderson JD (1973). Vigor determination in soybean by multiple criteria. Crop Science 13(6):630-633 . https://doi.org/10.2135/cropsci1973.0011183X001300060013x

Baskin CC, Baskin JM (1998). Seeds: Ecology, biogeography, and evolution of dormancy and germination. Academic Press, San Diego.

Baskin JM, Baskin CC, Li X (2000). Taxonomy, anatomy and evolution of physical dormancy in seeds. Plant Species Biology 15(2):139-152. https://doi.org/10.1046/j.1442-1984.2000.00034.x

Baskin CC, Baskin JM (2004). Germinating seeds of wildflowers, an ecological perspective. Horttechnology 14(4):467-473. https://doi.org/10.21273/HORTTECH.14.4.0467

Cho JS, Jang BK, Lee CH (2018). Seed dormancy and germination characteristics of the endangered species Cicuta virosa L. in South Korea. Horticulture Environment and Biotechnology 59(4):473-481.https://doi.org/10.1007/s13580-018-0062-

7

Cho JS, Lee CH (2018). Effect of germination and water absorption on scarification and stratification of kousa dogwood seed. Horticulture Environment and Biotechnology 59(3):335-344. https://doi.org/10.1007/s13580-018-0034-y

Farzami Sepehr M, Ghorbanli M (2011). Breaking of dormancy in Rhubarb (Rheum ribes L.). Iranian Journal of Plant Physiology 1(2):118-124.

Güngör F (2002). Investigation on the morphological, biological characteristics and cultivation possibilities of Eremurus spectabilis (Bieb.) Fedtsch, Prangos ferulacea (L.) Lindl. and Hippomaratbrum microcarpum (Bieb.) as growing wildly. PhD Dissertation, University of Atatürk (in Turkish).

Keskiner K (2017). Investigations on applications of breaking seed dormancy in grown wild Eremurus spectabilis M.Bieb. MSc Dissertation, University of Van Yüzüncü Y 1 (in Turkish).

Keskiner K, Tuncer B (2019). Dormancy breaking treatments for wild Eremurus spectabilis M. Bieb seeds. Fresenius Environmental Bulletin 28(2A):1167-1173.

Kırmızı S, Güleryüz G, Arslan H (2018). Effects of pretreatments on seed dormancy and germination in endemic Uludağ flax (Linum olympicum Boiss.) (Linaceae). Horticulture Environment and Biotechnology 59(5):629-635. https://doi.org/10.1007/s13580-018-0075-2

Li X, Baskin JM, Baskin CC (1999). Anatomy of two mechanisms of breaking physical dormancy by experimental treatments in seeds of two North American Rhus species (Anacardiaceae). American Journal of Botany 86(11):1505-1511. https://doi.org/10.2307/2656788

Mamut J, Tan DY, Baskin CC, Baskin JM (2014). Intermediate complex morphophysiological dormancy in seeds of the cold desert sand dune geophyte Eremurus anisopterus (Xanthorrhoeaceae; Liliaceae s.l.). Annals of Botany 114(5):991-999. https://doiorg/10.1093/aob/mcul64

Murillo-Amador B, López-Aguilar R, Kaya C, Larrinaga Mayoral J, Flores-Hernández A (2002). Comparative effects of NaCl and polyethylene glycol on germination, emergence and seedling growth of cowpea. Journal of Agronomy and Crop Science 188:235-247.https://doi.org/10.1046/j.1439-037X.2002.00563.x

Nikolaeva MG (1969). Physiology of deep dormancy in seeds (trans: by Z. Shapiro). Israel Program for Scientific Translations Ltd, Jerusalem.

Pourfarzad A, Najafi MBH, Khodaparast MHH, Khayyat MH, Malekpour A (2014). Fractionation of (Eremurus spectabilis) fructans by ethanol: Box-Behnken design and principal component analysis. Carbohydrate Polymers 106:374-383. https://doi.org/10.1016/j.carbpol.2014.01.048

Rahmanpour A, Majd A, Chalabian F (2005). Effects of gibberellic and citric acıd on germination percentage, speed of germination and seed vigor of (Eremurus spectabilis M.B). Iranian Journal of Rangelands and Forests Plant Breeding and Genetic Research 131(19):53-65. 
Akdağ Ş and Tuncer B (2020). Not Bot Horti Agrobo 48(2):1017-1026

Rahmanpour A, Majd A, Chalabian F (2007). The effect of hormones and mechanical treatments on seed germination of Eremurus olgae Regel. Iranian Journal of Medicinal and Aromatic Plants 23:1(35):111-120.

Rouhi HR, Shakarami K, Afshari RT (2010). Seed treatments to overcome dormancy of waterlily tulip (Tulipa kaufmanniana Regel.). Australian Journal of Crop Science 4(9):718-721.

Schiappacasse F, Szigeti JC, Manzano E, Kamenetsky R (2013). Eremurus as a new cut flower crop in Aysen, Chile: introduction from the Northern hemisphere. Acta Horticulturae 1002:115-121. https://doi.org/10.17660/ActaHortic.2013.1002.13

Tosun M, Ercisli S, Ozer H, Turan M, Polat T, Ozturk E, Padem H, Kilicgun H (2012). Chemical composition and antioxidant activity of foxtail lily (Eremurus spectabilis). Acta Scientiarum Polonorum Hortorum Cultus 11(3):145-153.

Tuzlacı E (1985). Çiriş plants of Turkey. Marmara Pharmaceutical Journal 1:69-89.

Tuzlacı E, Doğan A (2010). Turkish folk medicinal plants, IX: Ovacık (Tunceli). Marmara Pharmaceutical Journal 14:136-143.

OPEN ACCES

(c)
The journal offers free, immediate, and unrestricted access to peer-reviewed research and scholarly work. Users are allowed to read, download, copy, distribute, print, search, or link to the full texts of the articles, or use them for any other lawful purpose, without asking prior permission from the publisher or the author.

License - Articles published in Notulae Botanicae Horti Agrobotanici Cluj-Napoca are Open-Access, distributed under the terms and conditions of the Creative Commons Attribution (CC BY 4.0) License. (C) Articles by the authors; UASVM, Cluj-Napoca, Romania. The journal allows the author(s) to hold the copyright/to retain publishing rights without restriction. 